\title{
Incorporating languages into histories of war: a research journey
}

Article

Accepted Version

Footitt, H. (2012) Incorporating languages into histories of war: a research journey. Translation Studies, 5 (2). pp. 217-231. ISSN 1751-2921 doi:

https://doi.org/10.1080/14781700.2012.663606 Available at https://centaur.reading.ac.uk/25315/

It is advisable to refer to the publisher's version if you intend to cite from the work. See Guidance on citing.

To link to this article DOI: http://dx.doi.org/10.1080/14781700.2012.663606

Publisher: Taylor \& Francis

All outputs in CentAUR are protected by Intellectual Property Rights law, including copyright law. Copyright and IPR is retained by the creators or other copyright holders. Terms and conditions for use of this material are defined in the End User Agreement.

\section{www.reading.ac.uk/centaur}

\section{CentAUR}

Central Archive at the University of Reading

Reading's research outputs online 


\title{
Incorporating languages into histories of war: a research journey
}

\begin{abstract}
This article discusses the ways in which languages can be integrated into histories of war and conflict by exploring ongoing research in two case studies: the liberation and occupation of Western Europe (1944-47), and peacekeeping/peace building in Bosnia-Herzegovina (1995-2000).The article suggests that three methodological approaches have been of particular value in this research: adopting an historical framework; following the 'translation' of languages into war situations; and contextualizing the figure of the interpreter/translator. The process of incorporating languages into histories of conflict, the article argues, has helped to uncover a broader languages landscape within the theatres of war.
\end{abstract}

Traditional historical scholarship on war has been markedly ethnocentric. Military historians, in what is still predominantly an Anglophone discipline, tend to adopt a nation-state ontology of conflict, eschewing what Tarak Barkawi calls the, 'cultural mixing and hybridity of war' $(2006, \mathrm{x})$, in favour of a state against state, them against us framework in which 'foreignness' is positioned as an unproblematic given whose qualities are largely irrelevant to the themes that are being considered. In general, when languages appear in these narratives, they do so at the end of the story, represented as elements which are essentially benign, ancillary parts of those diplomatic relations which bring a conclusion to war (Roland 1999), or sources of useful pedagogic lessons for the post war period, like those which could be drawn from the US Forces' communicative language teaching techniques in the 1940s (Goodman 1947; Parry 1967). To date, the only detailed historical examination of a language policy within war itself is Elliott and Shukman's work on the secret classrooms of the Cold War (2002), and this is a study which concerns itself not with languages themselves, but rather with the social and cultural impacts which a programme of national language training might have on the servicemen concerned. More recently however, some historians engaged with pre-twentieth century conflicts 
have begun to question the traditionally accepted linguistic nationalism of the armies which were fighting in Europe in the medieval and early modern periods. Thus Kleinman (2009) traces the presence of Irish participants in the French armies of the late eighteenth century, and Butterfield (2009) challenges the monolithic 'anglophoneness' of British identity previously taken for granted by the majority of historians of the Hundred Years War. Such instances of the historical inclusion of languages are however rare. On the whole, the historiography of war continues to develop its key research questions within contexts which are foreign language free. In the Western historical academy, the business of military action conducted with or against different national and ethnic groups is typically assumed to be a monolingual operation, achieved through the language of the dominant force, or at least that of the observing historian or war studies commentator.

If war historians are largely uninterested in languages however, linguists and translation scholars have shown themselves to be increasingly curious about war and conflict, and in particular about the role that language intermediaries, interpreters and translators, might play in military situations (Apter 2006; Baker M. 2006; DragovicDrouet 2007; Inghilleri 2008, 2009; Rafael 2007; Salama-Carr 2007; Simon 2005; Stahuljak 2000, 2010). Often informed by a legacy of thought from cultural studies and literary theory (Bermann and Wood 2005), such researchers have sought to enlarge contemporary concepts of translation in ways which might be appropriate to 'translating culture in an age of political violence' (Tymoczko 2009, 179). Stahuljak (2000) for example has called on frameworks of testimony and witness in order to understand the voices of interpreters in conflict, whilst Baker has drawn on narrative theory to position translators as participants in the construction of war narratives (Baker M. 2006, 2010), and Inghilleri’s Bourdieusian approach positions interpreters 
within the social and professional contexts of war $(2005,2009$.). The result of this not inconsiderable body of research has been to emphasise the complex and multi-faceted roles of translators in conflict situations, thereby making important contributions to broader debates in translation studies concerning for example translator agency, and the ethics of translation itself. For these translation specialists, languages, far from being absent from military activity, are in effect part of the very institution of war, 'essential for circulating and resisting the narratives that create the intellectual and moral environment for violent conflict' (Baker M. 2006, 2).

What is interesting at this present time however is the wide gap which continues to exist between these two distinct parts of the academy - between the perception of translation studies scholars that language intermediaries are vital to war, and the total absence of languages, their occlusion, in the narratives which most historians construct of conflict and peace building. To some extent, one might argue that the failure to connect these two approaches has at its root the very distinct methodological traditions of the two disciplines - translation studies and history. In translation studies, much of the most innovative work on languages and war has been stimulated by recent Western deployments in Iraq and Afghanistan: 'You don't make war without knowing why? The decision to interpret in Iraq' (Inghilleri 2010); 'The ethical task of the translator in the geo-political arena from Iraq to Guantánamo Bay' (Inghilleri 2008); 'Relationships of Learning between Military Personnel and Interpreters in Situations of Violent Conflict' ( Tipton 2011); ' Translation, American English, and the National Insecurities of Empire' (Rafael 2009). In this research, conclusions about the place of languages in war are generally made on the basis of data relating to these contemporary deployments, with an implicit assumption that the position of the interpreter in such conflicts is likely to be somewhat similar to that in other wars; that 
war, and therefore the interpreter's role within it, will not necessarily change from one conflict to another. Historians on the other hand, whilst accepting that there are clearly tragic constants in war-making - killing, the victimisation of the innocent, the inequality of army/civilian relationships - generally view the activities associated with conflict as radically context-dependent, as being framed by those particular historical and geopolitical circumstances which have produced the war in the first place. Just as most historians would be uneasy extrapolating from one particular war in order to generalise about something like soldier/civilian relations, so any template of interpreter activity in conflict outside the specifically drawn circumstances of a particular war is likely to be viewed by historians as potentially unhistorical.

This article argues that it may be possible to bring the two sides of this academic debate into a closer dialogue, reconciling the emphasis on the role of interpreters /translators in war and the historical specificity of particular military situations within a broader perspective which seeks to uncover the role of 'languages' ( as opposed to language intermediaries) in war. The AHRC project on which the article is based Languages at War: policies and practices of language contacts in conflict (www.reading.ac.uk/languages-at-war/) - has as its aim the integration of languages into historical accounts of war, their embedding within narratives of conflict and peace building. Seeking to include languages in accounts of war, we rapidly discovered in this project, is to enter virtually uncharted methodological waters. In practice, our methodology has been developing incrementally as the project has progressed in relation to the material examined, the interviews conducted, and ongoing discussions with colleagues from a variety of disciplines: war studies historians, peacekeeping analysts, ethnographers, and translation studies specialists. Like Pym, we believe that, 'historians should grapple quite directly with their 
material, getting their hands dirty before elaborating any grand principles concerning the methodology of their task' (Pym 1998, viii). The Languages at War project is still ongoing, so that the suggestions that follow are largely provisional, reports back, as it were, from the research front. This article however outlines three broad approaches which we have found particularly helpful in integrating languages into accounts of war: adopting an historical framework; following the 'translation' of languages into war situations; and contextualizing the figure of the interpreter/translator.

\section{Adopting an historical framework}

Adopting an historical framework assumes a priori that there is no such thing as a typical war, that each conflict will have its own peculiar context. Conflict situations bring together a range of variables: the purpose and focus of the mission, the constitution of the military forces, the modes of encounter with civilians, and the composition and attitudes of local people. What tasks for example have the military been given in any particular conflict? Are they to occupy a country, liberate an area, pacify a region, make peace between warring groups, or build a long term and stable peace? Is their deployment expected to be short-term or extensive? Are the armies drawn from one nationality, or several? Have they been deployed as a national group, or are they organised with others, either in a loose coalition of foreign partners, or in a tighter treaty organisation? On the ground, do they seek to have direct relations with foreign civilians through their own personnel, or do they delegate some of these encounters to third party nationals, recruited directly 'on the ground', or brought in by a civilian agency? How do local attitudes towards the military differ according to the particular groups involved, and how do these attitudes change over time, perhaps mirroring the behaviour of the armies concerned and/or the evolution of the conflict 
itself? A robust analysis of languages data in war, we discovered, needs to be situated in this way, and to take account of key contextual issues.

In the Languages at War project, our approach has been to examine two specific case studies - the liberation and occupation of Western Europe (1944-47), and peacekeeping/peace building in Bosnia-Herzegovina (1995-2000) - selected as potentially providing different settings for the role of languages. In the Second World War, the mission given to Allied armies was to liberate enemy-occupied territories, and then to set up an occupation administration in Germany. In Bosnia-Herzegovina, the military were positioned firstly as peacekeepers between hostile ethnic groups, and then as peace builders, seeking to contribute to new relationships for the future. In the 1940s struggle, Allied troops, although brought together in a coalition from a range of nations, largely fought on the ground as separate entities in different theatres of war. In Bosnia-Herzegovina, Western armies were deployed as part of a wider peacekeeping force under the auspices of the UN/NATO, operating under national orders, but within a loose supra-national framework. In the Second World War, the huge armies of the Allied military were largely conscript soldiers, and overwhelmingly male. In Bosnia-Herzegovina, the forces were formed from smaller professional armies into which women had been at least partially integrated. In the Second World War, local attitudes towards incoming foreign troops varied from initial welcome to irritation and growing hostility in liberated territories. In occupied Germany, civilians found themselves living in a country dominated by foreign armies and burgeoning foreign bureaucracies, subject to physical and mental deprivations, with relatively little personal freedom of manoeuvre. The particularities of each situation were clearly likely to frame language experiences : thus for example linguists working for a section of the British administration in Germany would be 
operating in a very different context from those engaged by NATO in BosniaHerzegovina.

Any historical approach relies on robust sources. As Aldrich has suggested, historians, 'are ultimately what they eat' $(2002,149)$. Making visible the formerly invisible presence of languages, required, we found, the use of an eclectic and imaginative range of historical documents. Eclecticism of sources is of course partly a product of availability, of what can actually be found which is of relevance. In the case of the Second World War, relevant archival sources were often abundant but had seldom, if ever, been examined by previous historians. Thus for example, the development of translating/interpreting institutions for the British occupation of Germany - some 4,800 hours of translation work demanded every week by July 1945 - was clearly narrated in the records of the War Office and the Foreign Office. The way in which an Interpreters Pool had been established, with relevant personnel being recruited and tested, told us much about the often contradictory perceptions of security requirements - MI5 vetting typically rejected two out of every three candidates - and the urgency of operational needs. Initially, naturalized British subjects of allied or neutral origins, Eire nationals, or those of enemy origin were unable to work in the Pool, but by January 1945 demand for linguists was so heavy that most of these rules had been speedily relaxed. The addition of oral testimony (recorded by the Imperial War Museum before 2000) to this corpus of documentation provided a vivid picture of how these members of the Interpreters Pool actually operated on the ground, investigating war crimes, and interrogating prisoners of war. Newly recorded interviews with witnesses, focused specifically on languages in war, contributed an important additional element of participant self-reflection on the status and importance of languages over time (Tobia 2010 a,b.). In the case of Bosnia- 
Herzegovina, the conflict was too recent to have allowed for the archiving of a significant corpus of material in national collections and museums. In this situation, interviewing a wide range of participants was vital. Thus this case study recorded over fifty lengthy oral history interviews with locally recruited interpreters, military linguists, army personnel, and people working with NGOs and peacekeeping organisations, as well as using recently published memoirs from participants, and locally produced material.

An important aspect of the historical framework we adopted was a deliberate engagement with the relevant historiography in each case study. Chris Rundle and Kate Sturge in their work on translation history in fascist regimes have been at pains to take what they call an, 'outward-looking approach to translation history' (Rundle and Sturge 2010, 3). This is both a matter of being informed about what questions are currently being posed in the general historiography, and seeking to inform, to contribute to this historiography by moving if necessary beyond the 'comfort zone' of one's own initial discipline, both in publishing and in conference presentations. The analysis and coding of the rich oral material from the Bosnia case study yielded particularly valuable insights when placed within the context of existing scholarship on peacekeeping and strategic studies, and set alongside broader discussions of the nature of asymmetrical and gendered relationships in military and peace building operations. By contextualizing the primary material in this way, it was possible to produce a nuanced account of the role of languages in inter-relationships on the ground at the precise moment when a military organizational culture designed to facilitate war fighting was reorienting itself towards achieving peace and consent rather than victory (Baker, C. $2010 \mathrm{a}, \mathrm{b}$ ). An understanding of the role of languages in 
this conflict has been deepened by an engagement with wider discussions relating to peace keeping, stimulated by the Bosnia-Herzegovina struggle.

A classic case in which an understanding of the place of languages in conflict could arguably make some contribution to current historiography is that of the British Intelligence operation in the Second World War. The enormous and continuing critical attention given to the Bletchley Park phenomenon ( Hinsley, Simkins, and Howard 1979-90; Welchman 1982; Lewin 1978; Hinsley and Stripp 1994; Patterson 2008) has never to date involved any analysis of the 'foreignness' of the intelligence which was accessed, decrypted and utilized. In fact however the archives of Second World War Intelligence revealed in considerable detail the presence of a large and complex translation operation, with Naval Intelligence alone processing an average of 18,000 translations per month in the spring of 1944, and huge amounts of additional non-coded material - 10 tons of German documents arriving after the Liberation of Paris - needing to be translated. Without linguists, it is clear that Britain's Intelligence system would not have been viable, let alone effective. Languages are, in a very real way, a 'missing dimension' in historical discussions of intelligence at this period (Footitt 2010a).

\section{Following the 'translation' of languages into war situations}

Once the variables, sources and historiography of the case studies had been considered however, we still needed to develop approaches to uncovering the place of languages within the particular war situations. At an early stage in the project, we looked for what we termed, 'language encounters', examples of language exchange between the military and the local population. Quite rapidly however it became evident that this magpie approach, in effect imposing a pre-determined languages framework on war, was incomprehensible to a large number of participants in both 
conflicts, and bore little relation to what we were finding archivally. Increasingly we began to feel that discovering how languages were embedded in war situations would involve taking on some of the perspective of the military themselves, looking at the military chronology of events, examining the networks and associations which had produced the terms of any language exchange, and studying the physical as well as the verbal presence of languages on the ground of war.

Military operations, whether invasion or peacekeeping, tend to be organised in broad phases: pre-deployment, deployment (itself understood in discrete operational stages), and post deployment. Foreign Office committees, War Office reports, situation analyses, all followed this trajectory. Army participants interviewed related naturally to the military phases of operations, whilst civilian interviewees also placed their narratives within an overall military timescale, either by accepting the chronology presented, or positioning their experiences as implicit or explicit resistance to it. Adopting a military chronology of this sort made it possible for us to understand some of the conceptual heterogeneity of conflict: the competing agencies involved in pre-deployment preparations, and the experiences of different levels of operational command in distinct phases and geographies of the missions. In the case of Bosnia-Herzegovina for example, we found three periods of language support created by in-theatre operations at different times in the peacekeeping/peace building process. When British United Nations (UNPROFOR) troops first arrived in Vitez in November 1992, a hastily found military linguist recruited a handful of local interpreters, operating pragmatically with a small civilian language cell. With the deployment of a second British battalion, this cell approach was cascaded out. Although the international UNPROFOR headquarters were expected to manage language provision on the ground, their remoteness from the actual sites of operation 
meant in effect that national contingents had to make their own language arrangements. The end of UNPROFOR's mission in December 1995, after the signing of the Dayton agreement, brought massive organisational change to the multinational military mission in Bosnia-Herzegovina, and this was reflected directly in the lives and employment opportunities of interpreters. These very specific military contexts conditioned the language experiences of all participants, and were used by interviewees as a way of framing their narratives.

Although military attitudes to foreign language provision appeared to be key in setting the terms of 'on the ground' encounters, it proved initially difficult to find evidence of explicitly named 'language policies' which the military forces had adopted when preparing for their operations. Spolsky's 'Language Management' approach was helpful in pointing out the influence which the organizational structure of an army - the different foreign language requirements of sergeant, commander, spy and occupier for example - could play in the formulation of policies. His corollary however that the military domain is a relatively easy arena in which to examine language management, 'Because... an army is able to focus its resources and apply its in-built authority to language as well as its other goals' (Spolsky 2009, 143), is somewhat at odds with what we observed to be the political and military 'messiness' of the actuality of war, and hence the difficulties inherent in establishing language policies for it. In contemporary armed forces for example, the place of foreign languages in pre-deployment preparations is very far from clear. Whilst 'culture' is a term which the military prioritise and seek to integrate in their preparations, the space explicitly occupied by foreign languages is vague and uncertain. A recent Joint Doctrine paper, 'The Significance of Culture to the Military', set out in detail the reasons why culture is important in war and suggested specific ways in which military 
capability in this area might be strengthened through cultural analysis templates and frameworks of cultural capability. Out of 508 closely argued paragraphs however, only three were devoted to the role of foreign languages. The evident epistemological unease about the relationship between language on the one hand and culture on the other positioned foreign languages as an essentialized entity, related to culture in some problematic and largely unexplored way, but distinctly separate from it: 'Cultural and language capability are inextricably linked. An appreciation of culture facilitates the use of language, whilst linguistic skills facilitate the gaining and exploitation of cultural knowledge. However, knowledge of a language does not directly equate to knowledge of a culture. If language is what is said, culture influences what is meant' (Ministry of Defence 2009, 1/5).

In the case studies in this project the language implications of military deployment to a foreign country were often implicitly rather than explicitly addressed in policy terms, and usually in response to a complex nexus of factors in which perceptions of the 'other', attitudes to one's own language, political objectives, and departmental infighting were as important as the requirements of fast-moving military operations. Rather than starting from a platonic ideal of what 'language policy' might be, or relating it solely to levels of organizational command, army institutional culture, or the employment of quasi professional linguists, we found it more helpful to start from the ground of conflict itself, tracing the ways in which the idea of foreign languages was, in Bruno Latour's formulation, 'translated' into military preparations for deployment. For Latour, translation does not primarily refer to a linguistic notion, but rather to the stages by which an idea gradually moves into becoming a (scientific) fact, how a particular product/idea and the demand for that product/idea are simultaneously created. It is vital in this sense that, 'the vocabulary of the actors' is 
heard loud and clear, in a landscape which is conceptually flattened so that networks and associations can be followed, with no necessary distinction between the macro and the micro (Latour 2007, 30).

Looking at pre-deployment preparations for the Liberation of Western Europe for example, we explored how the networks involved in producing briefing materials for troops modified and negotiated their various interests, and hence how foreign languages were produced or 'translated' into these war preparations. Following the development of the cultural briefing materials that came from such networks provided an understanding of language policy which was closely related to the authorities' own perceptions of their objectives as they prepared some three and a half million men for deployment to eight different continental countries. Thus, the political imperative to prevent troops behaving disrespectfully to liberated populations framed an idea of foreign languages as part of a tool kit for the 'good ambassador' soldier. A desire to ensure that the trooper was aware of the existence of a language different from his native tongue, and that he would approach the liberated populations with courtesy produced specific advice on how to use English with politeness when speaking with foreign civilians ('Don't shout when you are talking to a Dane'), and sensible linguistic tips on how to communicate when you possess only a minimum competence in the foreign language ('Never ask a question which requires a long answer: you won't understand'). Planners' efforts were concentrated on suggesting the qualitative nature of imagined future relationships during the Liberation where it was hoped that mutual respect and patience would characterise civilian/military meetings (Footitt 2010b.). In the context of cultural preparations for troops, the presence of foreign languages was thus produced and given meaning in good behaviour guides, where 
language etiquette, rather than any form of language competence, was what was considered to be important.

In deployment too, overall military policies translated languages into facts within the theatre of war, affecting the military forces, the local community, and those who moved between them as language intermediaries. The British occupation of Germany in the mid 1940s for example was characterised from the beginning by a desire to maintain social distance between governors and governed, establishing an apparatus and structure of administration which would be expressed solely in the native tongue of the occupiers. The only language of government was to be English: ' It is felt that the onus of understanding orders and instructions issued to the Germans should rest with the Germans, and that error of translation or speech should provide no justification for the Germans in failing to carry out our requirements'. ${ }^{1}$ A briefing paper given to every new member of the Control Commission in Germany advocated a linguistic persona which differentiated between public presentation on the one hand, and private understanding on the other: 'DO use English in your official dealings with the Germans; DON'T try to air your knowledge of German; DO learn German and all you can about Germany and the Germans'. ${ }^{2}$ As the administrative structures in the British zone of occupation developed, a battlement of Anglophone bureaucracy had to be replicated by a second ring of German personnel (some 30,584), charged with actually communicating the messages of the occupying authorities to German civilians, and implementing its orders. Such staff were often recruited in the first place because of their knowledge of English rather than because they were natural and enthusiastic supporters of British occupation policies. The language of the military served to create a hermetically sealed space for an English-speaking community, deliberately distanced from the surrounding locals: 'At present foreigners live in a 
world separate from that of the Germans....This means that there are two widely different worlds in Germany'. ${ }^{3}$

In Bosnia-Herzegovina, the urgent military need to find English speakers among the local civilians inevitably gave status and employment to people who had linguistic skills to offer. To begin with these employees were often very young, students who had only just left high school but who possessed a reasonable level of English. The early period of deployment was one with an enormous demand for English speakers, when salaries were high, so that those who found employment - usually the young, and very often women - found themselves in a highly advantageous financial position in relation to the rest of their communities. Language requirements thus operated at this time to change the social and economic balance of the communities in question. The extreme pay differentials between employees of international organisations and their neighbours were to remain a characteristic of life in Bosnia-Herzegovina long after the Dayton agreement. Commenting on what lessons might be learned from this situation for the contemporary deployment in Kosovo, US diplomat Robert Barry commented: 'We should not let the international agencies and NGOs coming to Kosovo do what they did in Bosnia - bid against each other for qualified local staff. Doing so results in people who should be the judges and editors becoming the drivers and interpreters at wages higher than cabinet ministers receive' (Barry 1999, 102).

The 'translation' of languages into the theatre of war was of course as much physical as verbal. Languages were embodied on the ground of conflict, inscribed physically in the landscapes in which troops were deployed. Whatever the purposes of foreign troops entering a country - liberation, occupation, humanitarian assistance, peacekeeping - they effectively occupied its space, imposing their own geography on what was to them a deeply unfamiliar territory. Whether the military constructed new 
bases or reused existing structures, it adapted local space to its own purposes, accommodating hundreds or thousands of foreign soldiers whose knowledge of the local languages was usually minimal. In this process, the cartography of the country was changed, and domestic maps remade. In Bosnia-Herzegovina after the Dayton Peace Agreement, the maps of the international forces overlaid the boundaries of the coalition's three Multi-National Divisions. In 1944, the American Army mapped its supply routes around Cherbourg on roads it described as the 'Green Diamond Highway' (Cherbourg-St-Lô, Cherbourg- Dol), and the 'Red Ball Highway' (St-LôVire). The military presence inevitably affected the local topography, taking over buildings and radically changing their usage. By early 1945 for example, the Americans in Reims were occupying 17 factories, 41 garages, 5 cinemas, 4 dance halls, 3 barracks, 2 hospitals, 68 hotels, 12 restaurants, 122 flats, 260 rooms in private houses, 5 schools, the Stade Municipal, the town's music conservatory, public gardens, and 6 of the major arterial roads in the city. ${ }^{4}$

Formal and informal practices of renaming space are of course ubiquitous, exerting what Pratt describes as 'the power of naming' (Pratt 1992, 33). In this process, a perception can develop that naming a space amounts to the same as possessing it, and that once one has the space already in one's possession, there is no real need to strive towards understanding. As Brossat noted $(1994,8)$, one of the very first actions of people in liberated France had been to tear down those physical marks of German occupation, the street signs and notices on buildings, which had marked out the enemy presence. In occupied Germany, the British authorities renamed the buildings they were using as offices and bases - 'Lancaster House', 'Stirling House' - replacing the original German nomenclature. In Bosnia-Herzegovina, where the foreign presence had implicitly arrived with the consent of all three main local politico- 
military forces, the way in which the local landscape was renamed in English (the working language of the coalition) was strikingly similar to what had happened in the Second World War. The anthropologist Coles recalled an incident in which a fellow election monitor, seeing English-language route names on a foreign map of BosniaHerzegovina, initially thought that the mapped territory was part of the United States (2007, 63). Officially mapped names aside, foreign soldiers often renamed the spaces around them as slang, abbreviating or corrupting hard-to-pronounce words. Thus in Bosnia, soldiers would call 'Bugojno' 'Bugonyo'. 'Gornji Vakuf' and ‘ Mrkonjic Grad' would become 'GV' and 'MG' respectively. ${ }^{5}$ In both case studies, naming by foreign troops served as a marking out of occupied spaces, a way of separating the incoming military from the local community, producing what some described in occupied Germany as a 'compound atmosphere', 6 or in the Balkans as a hyper-reality, 'hyper-Bosnia' (Coles 2007, 64). Beyond the esoteric language/culture debates which

persist today among sections of the Western military, these case studies suggested that languages were in fact 'translated' into the theatre of war, embedded in overall military plans and chronology, operating in deployment to condition future encounters 'on the ground', economically, socially and physically.

\section{Contextualizing the figure of the interpreter/translator}

In all this work, the figure of the language intermediary, the interpreter or translator, remained a crucially important aspect of Languages at War. Much of the recent research on interpreters in war has of course problematized the traditional paradigm of the interpreter as an ethically neutral mouthpiece. As Kahane, a member of the International Association of Conference Interpreters (AIIC), argued, this ideal of professional neutrality sits uneasily both with the history of interpreting, and with the demands of contemporary life: 
The notion of the unsullied interpreter who extracts the essentials of a message and transforms them into another language without sharp edges and roughness in the interests of communication and on the fringes of the contexts and intentions that exist well beyond the act of communication is a recent idea - what are 60 years? - that sits awkwardly with the profession's history and with the world we live in (Kahane 2007).

In much of translation scholarship, expectations of professional neutrality for the interpreter in war have largely given way to an acceptance that living with divided loyalties may be the inevitable lot of those who work as language intermediaries in war, a situation which could for example be actively exploited in order to support a particular cause (Tymoczko 2000; Stahuljak 2010), or passively accepted in order to disseminate public narratives associated with the conflict (Baker M. 2006). Expected or imagined loyalty/disloyalty however are situated concepts which may relate less to the particular role of an interpreter per se and more to the specific concatenation of circumstances which has constructed the theatre of war in the first place. Interpreters /translators are not only placed in the position of intermediaries, in between camps or groups of belligerents, but are also integrated within the ongoing development of the war situation. We felt increasingly in this project that contextualizing the interpreters /translators more overtly - placing them back within the particularities of the war situation - might help us to develop a focus broader than the loyal/disloyal trope, thus seeing language intermediaries as one of the elements within a more holistic landscape into which languages had been 'translated'.

In Bosnia-Herzegovina, even those foreign forces which had invested the most in military language training (such as the UK and the Dutch) were able to meet only a 
small fraction of their linguistic needs themselves, so that the majority of those who interpreted for foreign forces were locals, selected for their spoken English, confidence and self-reliance. These people undoubtedly found themselves in a maelstrom of clashing loyalties, but it was a maelstrom which was arguably not that different from the clash of loyalties then engulfing the whole country. Most participants in the Bosnia-Herzegovina struggle were implicated in an ongoing process of contesting or acquiescing in others' attempts to situate them within collective identities: 'locals', 'internationals', 'the Serbs', 'the Croats', 'the Muslims', 'the Brits', 'the UN', 'townspeople', 'refugees', and so on. The ethno-political logic of the war, and indeed of the peace settlement, conditioned these collectivising responses but they also had their roots in longer-term legacies of trust and mistrust. In effect interpreters were operating within the same field of clashing and dissonant loyalties as most of their fellow countrymen. ${ }^{7}$ What distinguished them of course was their perilous physical visibility at points of violent tension, their assumed proximity to the most foreign and supposedly neutral of all the groups (foreign peacekeepers), and their primary responsibility for achieving some kind of communication with the personnel they were tasked to meet. For locally recruited interpreters, working as a language intermediary in this situation was one means of recovering agency and selfhood in besieged cities or economically depressed post-war towns. Finding agency and individuality via normatively invisible acts of translation and interpretation could however pose major problems. Active subjectivity (playing on one particular ethnic identity in order to reconcile a difficult situation for example) could take an immense psychological toll on the individual ( Stankovic 2000). It might also conflict with the received contemporary wisdom of what an interpreter should actually be, as derived for example from crash courses at the Defence School of Languages in the UK, where 
trainees were taught to minimize their presence in conversations: 'At Molesworth (airbase), the Americans used to call the interpreters 'lips'. 'Hey, lips' you know, and the lips would come over and do the interpreting and they were supposed to be invisible, ${ }^{8}$

By comparison with the situation in Bosnia-Herzegovina, the European languages required by the military in the Second World War were much more widely available within the British context. Thus for example linguists needed for the Intelligence Service during the war could largely be recruited from within the national community. In the secret listening stations (Y stations) which were set up all around the coast of Britain to intercept messages from enemy aircraft and shipping, women already in uniform who could speak German were drafted in. This sort of linguistic fluency was most likely to have been acquired through an extensive period of residence in the country before the war, and the first wave of recruits accordingly tended to be middle class women, often educated outside the UK, from wealthy cosmopolitan backgrounds, aptly nicknamed in the circumstances 'The Boarding School Girls' (Clayton 1980, 56). In comparison, personnel recruited to the Government's Code and Cypher School at Bletchley Park were required to have only a reading knowledge of the language: 'enough German simply to read it (not to speak nor write it)', and this only if other desirable attributes - intellect, energy and common sense - were demonstrably present as well'. ${ }^{9}$ The status accorded to those who worked as linguists at Bletchley Park was considerably higher than that of the operatives in the Y stations, a reflection both of the gender differential (men at Bletchley Park, women in the Y stations), and probably too of the greater respect accorded at that time to reading the language as opposed to speaking it. In both cases, the authorities recruited from the tried and tested networks of influence (public schools, Oxford and Cambridge, and 
their related circles) so that those who acted as language intermediaries in this way were well integrated within the social and economic governing classes of the country.

When the Allies landed in continental Europe, and particularly when they were embarking on the occupation of Germany however, a much larger group of language intermediaries was needed, people who would be able to converse with the enemy, find out relevant intelligence, and investigate and prosecute war criminals. Rather than recruiting locally for these tasks, the Allied authorities placed greater reliance on the reservoir of 75,000 German and Austrian Jews who had come to Britain between 1933 and 1939, of whom approximately one in seven had enlisted in the British army ( Fry 2009, xi). These men and women, who had changed their names during the war years in order to avoid being treated as traitors if captured, wore British army uniform, and were generally keen to assimilate; ' we were British soldiers now, we didn't want to speak German'. ${ }^{10}$ When interrogating a prisoner of war, or acting as an interpreter, these ex-refugees largely maintained their new British identity: 'One didn't have to explain, I spoke German like a German of course $\{\ldots .$.$\} uhm it was$ while interrogating Germans, German soldiers that I might be asked how come you speak such good German, and at that point I might have to remind them that I was here asking questions, and they would please give the answers'. ${ }^{11}$ Rather than being caught up in a nation-wide clash of loyalties as in Bosnia-Herzegovina, language intermediaries in the Second World War were marked by assimilation, either within the prevailing class structure, or within a British military identity which they had at least in part chosen.

It is true of course that placing language intermediaries within the specifics of the war situation and the 'translation' of languages within it may offer few additional insights about the actual practices of interpreting in war. This more holistic approach 
however - seeing interpreters/translators as one element in an overall linguistic landscape which has been produced by war - can serve to extend our understanding of the range of circumstances which has brought the interpreters to their present posts, and hence the gamut of personal and professional concerns they may have. In both case studies the figure of the interpreter came to embody some of the political, social and economic circumstances of the specific war. In a sense the language intermediary was exposed, not only as someone placed in between combatants at high points of danger, but also as the embodiment of those disruptions which particular wars and conflicts engender in their societies.

\section{Conclusions}

The approaches developed in this project have aimed to incorporate languages into accounts of conflict by a process of contextualization which seeks to uncover a languages landscape within war. The historical framework we adopted involved a consideration of the variables, sources and historiography specific to each case study. A desire to trace how languages were 'translated' into war led us to look in detail at the military themselves, their chronology, the networks and associations which developed language policies, and the appearance of languages, both verbally and physically on the 'ground of war'. This holistic approach to perceiving languages meant that the language intermediary became one element within this linguistic landscape, situated within the particularities of the conflict, and exhibiting qualities which were as much related to the specifics of the conflict and the broader 'translation' of languages, as to more general paradigms of interpreting/translating, whether professional or based on imagined loyalty/disloyalty. If incorporating languages into histories of war has sometimes seemed to us like a research journey into the methodological unknown, it has at least challenged us to widen our 
understanding both of war and of the place of languages within it. The business of war has seldom been a monolingual one. Whether we choose to notice it or not, the 'ground of war' is almost always a linguistic landscape.

\section{Acknowledgements}

This work is part of the AHRC-sponsored project, Languages at War. Policies and Practices of Language Contacts in Conflict. I would like to thank the AHRC for its support, and my colleagues in the research team - Louise Askew, Catherine Baker, Michael Kelly, James Taylor, Greg Tinker and Simona Tobia - for their active participation in the research, and for their discussion of this article.

Key Words: Languages, Translators, Interpreters, World War II, BosniaHerzegovina, Military.

\section{References}

Aldrich, Richard. 2002. “ “Grow your own”: Cold War Intelligence and History Supermarkets', Intelligence and National Security, 17(1): 135-152.

Apter, Emily. 2006. The Translation Zone. Princeton/Oxford: Princeton U.P.

Baker, Catherine. 2010a. " “ It's not their job to soldier”. Distinguishing Civilian and Military in Soldiers' and Interpreters' Accounts of Peacekeeping in Bosnia-Herzegovina', Journal of War and Culture Studies, 3(1): 137-150.

Baker, Catherine. 2010b. “ " The Care and Feeding of Linguists”: the Working Environment of Interpreters, Translators and Linguists during Peacekeeping in Bosnia-Herzegovina', War and Society. 29(2): 154-175.

Baker, Mona. 2006. Translation and Conflict. A Narrative Account. London/New York: Routledge.

Baker, Mona. 2010. ' Interpreters and Translators in the War Zone. Narrated and narrators'. The Translator. 16 (2): 197-222.

Barkawi, Tarak. 2006. Globalization and War. Maryland: Rowan and Littlefield.

Barry, Robert L. 1999. 'Lessons Learned from Bosnia’, Helsinki Monitor, 3: 100-102.

Bermann, Sandra and Michael Wood (2005). Nation, language and the ethics of translation. Princeton and Oxford: Princeton UP. 
Brossat, Alain. 1994. Libération, fête folle, 6 juin 1944- mai 1945: Mythes et Rites, ou le Grand Théâtre des Passions Populaires, Série Mémoires 30. Paris: Editions Autrement.

Butterfield, Ardis. 2009. The familiar enemy: Chaucer, language and nation in the Hundred Years War. Oxford: OUP.

Coles, Kimberley. 2007. Democratic Designs: International Intervention and Electoral Practices in Postwar Bosnia-Herzegovina. Ann Arbor, MI: University of Michigan Press.

Clayton, Aileen. 1980. The Enemy is listening. London: Hutchinson.

Dragovic-Drouet, Mila. 2007. 'The practice of translation and interpreting during the conflicts in the former Yugoslavia (1991-1999)', in Translating and Interpreting Conflict. ed. Myriam Salama-Carr. Amsterdam/New York: Rodopi: 29-40.

Elliott, Geoffrey and Harold Shukman. 2003. Secret classrooms: a memoir of the Cold War. London: St. Ermin's.

Footitt, Hilary. 2010a ‘Another Missing Dimension? Foreign Languages in World War II Intelligence', Intelligence and National Security, 25 (3): 271-289.

Footitt, Hilary. 2010b. 'Languages at War: Cultural Preparations for the Liberation of Western Europe', Journal of War and Culture Studies. 3 (1): 109-121.

Fry, Helen. 2009. Churchill's German army. Stroud: the History Press

Goodman, S.M. 1947. Curriculum implications of Armed Services education programs. Washington D.C.: American Council on Education.

Hinsley, Harry; C.A.G Simkins; H. Howard. 1979-1990. British Intelligence in the Second World War. London: HMSO.

Hinsley, Harry and A. Stripp. 1994. Code Breakers. The Inside Story of Bletchley Park. Oxford:OUP.

Inghilleri, Moira. 2005. "The sociology of Bourdieu and the construction of the "object" in translation and interpreting studies'. The Translator 11 (2). Special Issue: 125-145.

Inghilleri, Moira. 2008. 'The ethical task of the translator in the geo-political arena: from Iraq to Guantánamo Bay’, Translation Studies 1 (2): 212-223.

Inghilleri, Moira. 2009.' Translators in War Zones: ethics under fire in Iraq', in Globalization, political violence and translation, ed. Esperanza Bielsa and Christopher Hughes, Basingstoke: Palgrave Macmillan: 207-221.

Inghilleri, Moira (2010). " "You don't make war without knowing why." The decision to interpret in Iraq'. The Translator. 16 (2): 175-96.

Kahane, Eduardo 2007. 'Interpreters in conflict zones: the limits of neutrality'. AIIC webzine. Summer 2007. www.aiic.net/ accessed 14 August 2011.

Kleinman, Sylvie. 2009. 'Un brave de plus: Theobald Wolfe Tone, alias Adjutant-General James Smith, French officer and Irish patriot adventurer, 1796-8' in Franco-Military connections, 1550-1945. Proceedings of the Vincennes Conference, September 2007, ed. Nathalie Genêt-Rouffiac and David Murphy, 163-188. Dublin: Four Courts Press.

Latour, Bruno. 2007. Reassembling the Social. An Introduction to Actor-Network Theory. Oxford: OUP.

Lewin, Ronald. 1978. Ultra goes to War: the Secret Story. London: Hutchinson. 
Ministry of Defence. 2009. Joint Doctrine Note: The Significance of Culture to the Military (JDN 1/09). Bicester: DSDA.

Parry, Albert. 1967. America learns Russian. Syracuse: Syracuse UP.

Patterson, Mike. 2008. Voices of the Code Breakers. Cincinatti: David and Charles.

Pratt, Mary Louise. 1992. Imperial Eyes: Travel Writing and Transculturation. London/New York: Routledge.

Pym, Anthony. 1998. Method in Translation History. Manchester: St. Jerome.

Rafael, Vicente. 2007. 'Translation in Wartime', Public Culture 19 (2): 239-46.

Rafael, Vicente. 2009. 'Translation, American English, and the National Insecurities of Empire', Social Text 101. 27 (4): 1-23.

Roland, Ruth. 1999. Interpreters as diplomats. Ottawa: Ottawa UP.

Rundle, Christopher; Kate Sturge (eds.), 2010. Translation under Fascism. Basingstoke: Palgrave Macmillan. 2010.

Salama-Carr, Myriam. 2007. Translating and Interpreting Conflict. Amsterdam/New York: Rodopi.

Simon, Sherry (ed.).2005 Translation and Social Activism, Special Issue of TTR: Traduction,

Terminologie, Rédaction. 18 (2).

Spolsky, Bernard. 2009. Language Management. Cambridge: CUP.

Stahuljak, Zrinka 2000. 'Violent distortions: Bearing Witness to the task of Wartime Translators', TTR: Traduction, Terminologie, Rédaction 13 (1): 37-51.

Stahuljak, Zrinka. 2010. 'War, Transnationalism. Interpreters in and out of the War (Croatia, 19911992)', in Critical Readings in Translation Studies, ed. Mona Baker. London/New York: Routledge: 391-414.

Stankovic, Milos. 2000. Trusted mole: a soldier's journey into Bosnia's heart of darkness. London: HarperCollins.

Tipton, Rebecca. 2011. 'Relationships of learning between military personnel and interpreters in situations of violent conflict', The Interpreter and Translator Trainer 5 (1). Special Issue: 15-40.

Tobia, Simona. 2010a. 'Questioning the Nazis: Language and Effectiveness in British War Crime Investigations and Trials in Germany, 1945-48', Journal of War and Culture Studies. 3(1): 123-136.

Tobia, Simona. 2010b. 'Crime and Judgement: Interpreters/Translators in British War Crimes Trials, 1945-49’, The Translator.16(2): 275-293.

Tymoczko, Maria. 2000.' Translation and political engagement: activism, social change and the role of translation in geopolitical shifts'. The Translator. 6 (1): 23-47.

Tymoczko, Maria (2009). ' Translation, Ethics and Ideology in a Violent Globalizing World', in Globalization, political violence and translation, Esperanza Bielsa and Christopher Hughes (ed.). Basingstoke: Palgrave Macmillan: 2009: 171-194.

Welchman, Gordon. 1982. The Hut Six Story: Breaking the Enigma Codes. London: Allen Lane. 
${ }^{1}$ National Archives, Kew (NA), WO 229/69/9, Draft Instruction (undated): G5 submission, 7 December 1944.

${ }^{2}$ NA, FO 1032/1462, Documents on 'The German Character', 1 March 1945.

${ }^{3}$ NA, FO 1030/320, Notes on a visit to Germany, 30 December 1945.

${ }^{4}$ Archives Départementales, Marne, 3Z 874, Service d'Aide aux Forces Alliées de la Mairie de Reims to Sub-Prefect, 8 May 1945.

${ }^{5}$ Interviews, C. Baker, February 2009; May 2010.

${ }^{6}$ NA, FO 1014/26, Clegg Report, 31 May 1948.

${ }^{7}$ I am indebted to C. Baker for this insight.

${ }^{8}$ Interview, C. Baker, September 2009.

${ }^{9}$ NA, HW 3/119, 'History of Hut 3, 1940-45', vol. I, 49.

${ }^{10}$ Interview, S. Tobia, December 2009.

${ }^{11}$ Interview, S. Tobia, December 2009. 